Ambiente \& Água - An Interdisciplinary Journal of Applied Science
ISSN 1980-993X - doi:10.4136/1980-993X
www.ambi-agua.net
E-mail: ambi.agua@gmail.com

\title{
Sunflower biometrics and chemical salinity attributes of soil irrigated with waters of different qualities
}

\author{
ARTICLES doi:10.4136/ambi-agua.2499
}

Received: 25 Nov. 2019; Accepted: 04 Jun. 2020

\author{
Paulo Vitor Santa Rosa Silva ${ }^{* * i D}$; Patricia dos Santos Nascimento ${ }^{2}$ \\ ${ }^{1}$ Centro de Ciências Agrárias, Ambientais e Biológicas. Universidade Federal do Recôncavo da Bahia (UFRB), \\ Rua Rui Barbosa, n 710, CEP: 44380-000, Cruz das Almas, BA, Brazil. \\ ${ }^{2}$ Departamento de Tecnologia. Universidade Estadual de Feira de Santana (UEFS), Avenida Transnordestina, S/N, \\ CEP: 44036-900, Feira de Santana, BA, Brazil. E-mail: patricianascimentouefs@gmail.com \\ *Corresponding author. E-mail: paulovitor.srs@ hotmail.com
}

\begin{abstract}
Poor quality water, such as sewage, has become an alternative to reduce the consumption of good quality water by irrigation, especially in arid and semi-arid regions; however, water rich in salts can be harmful to agricultural systems. This research evaluated the impacts of salinity of waters of different qualities on the development of the sunflower culture and on the soil. The research was developed in the area of the Environmental Studies Team (EEA/UEFS), and the experimental design used was completely randomized, consisting of four treatments: rain water $\left(0.20 \mathrm{dS} \mathrm{m}^{-1}\right)$, well water $\left(1.50 \mathrm{dS} \mathrm{m}^{-1}\right)$, cesspool effluent $\left(3.50 \mathrm{dS} \mathrm{m}^{-1}\right)$ and brackish water $(5.00$ $\mathrm{dS} \mathrm{m}^{-1}$ ), with the irrigation manually done and the blade calculated based on daily evapotranspiration. Irrigation with effluent promoted a better development of the sunflower crop, and the increase in the salinity of the irrigation water in the other treatments promoted a decrease in the total fresh and dry phytomasses, plant height, stem diameter, number of leaves, leaf area, internal and external diameters of the capitula and in the consumption and efficiency of water use. The use of rainwater, well water and cesspool effluent proved to be suitable for irrigation of the sunflower crop; however, the latter sodified the soil, which would already be recommended for the application of treatments for soil recovery.
\end{abstract}

Keywords: agriculture, salts, wastewater.

\section{Biometria do girassol e atributos químicos de salinidade do solo irrigado com águas de diferentes qualidades}

\section{RESUMO}

As águas de má qualidade, como os esgotos, têm se tornado uma alternativa para reduzir o consumo de águas de boa qualidade pela irrigação, principalmente em regiões áridas e semiáridas, porém, águas ricas em sais podem causar efeitos deletérios aos sistemas agrícolas. Objetivou-se com essa pesquisa avaliar os impactos da salinidade de águas de diferentes qualidades no desenvolvimento da cultura do girassol e no solo. A pesquisa foi desenvolvida na área da Equipe de Estudos Ambientais (EEA/UEFS), e o delineamento experimental utilizado foi o inteiramente casualizado, constando de quatro tratamentos: água de chuva $\left(0,20 \mathrm{dS} \mathrm{m}^{-1}\right)$, água de poço $(1,50$ $\left.\mathrm{dS} \mathrm{m} \mathrm{m}^{-1}\right)$, efluente de uma fossa séptica $\left(3,50 \mathrm{dS} \mathrm{m}^{-1}\right)$ e água salobra $\left(5,00 \mathrm{dS} \mathrm{m}^{-1}\right)$, sendo a irrigação feita manualmente e a lâmina calculada com base na evapotranspiração diária. A irrigação com 
o efluente da fossa promoveu um melhor desenvolvimento da cultura do girassol, e o aumento da salinidade das águas de irrigação nos demais tratamentos, promoveu um decrescimento das fitomassas frescas e secas totais, na altura de planta, diâmetro do caule, número de folhas, área foliar e nos diâmetros interno e externo dos capítulos, no consumo e na eficiência do uso de água. O uso da água de chuva, de poço e do efluente da fossa se mostraram adequadas para irrigação da cultura do girassol, porém, a última solidificou o solo, o que já seria recomendável à aplicação de tratamentos para recuperação dos solos.

Palavras-chave: agricultura, água residuária, sais.

\section{INTRODUCTION}

Water characterized as wastewater and saline must always be considered as alternative sources for less restrictive uses and to maintain agricultural production in water-scarcity environments. However, the presence of salts in these irrigation waters can be a difficult scenario and an obstacle to the introduction of these waters in production systems, as these salts can influence the germination, growth, production and nutrition of plants.

Salinity affects crops in two ways: as the concentration of salts in the soil increases, so does the osmotic potential of the soil, and the more saline a soil is, the more energy will be spent by plants to absorb water and the elements vital to their development; and the toxicity of elements such as boron, sodium, bicarbonates and chloride causes physiological problems for crops (Silveira et al., 2016).

When commercially exploring a crop, it is very important to take into account the effects of salts on its growth and development parameters as well as the adverse phenomena involved, as this can lead to an appropriate management of irrigation and cultivation, in order to allow the use of lower quality waters (Dias et al., 2016).

However, despite its disadvantages, the use of wastewater as an irrigation source has been an effective strategy in dealing with the scarcity of water resources in arid and semi-arid regions (Azevedo et al., 2013), and its use allows the recycling of water and nutrients, providing the production systems of these regions with a greater availability of water and reduced costs for fertilizers (Santos Júnior et al., 2014).

Wastewater provides several micro and macronutrients for plants, mainly nitrogen, phosphorus and potassium, necessary for their growth. Nitrogen stands out for being one of the main nutrients related to increased yield and for playing a fundamental role in plant growth, being responsible for structural functions and for being part of the composition of proteins, proline and amino acids. Phosphorus has been one of the macronutrients that most limit production, while potassium favors the formation and translocation of carbohydrates and activation of enzymes involved in breathing (Aminifard et al., 2010; Ahmadifard, 2014).

Several researches have pointed out the possibility of irrigation of several plant species with poor quality water, being a widely studied practice and recommended by several researchers and water managers. From a nutritional point of view, studies have shown positive effects of irrigation with high salinity water, such as sewage, on the production and productivity of vegetables, proving the fertilizing effect of wastewater in numerous studies and in various cultures such as sunflower (Santos Júnior et al., 2014; Oliveira et al., 2017), pepper (Silva et al., 2019), melon (Costa et al., 2014), corn (Malafaia et al., 2016), tomato (Jorge et al ., 2017) and watermelon (Salgado et al., 2018).

The good adaptation of the sunflower to different climates and regions, its economic importance, and the moderate tolerance to salinity motivated the selection of the crop for research. Therefore, this study evaluated the development of sunflower culture as a function of irrigation with waters of different qualities and salinities.

Rev. Ambient. Água vol. 15 n. 4, e2499 - Taubaté 2020 


\section{MATERIAL AND METHODS}

The research was carried out in an open field at the headquarters of the Environmental Studies Team (EEA) at the State University of Feira de Santana (UEFS), in the municipality of Feira de Santana. The municipality of Feira de Santana is located in the semi-arid region of the state of Bahia, with geographical coordinates $12^{\circ} 16^{\prime} 00$ south latitude and $38^{\circ} 58^{\prime} 00$ west longitude of Greenwich.

The experimental design used was completely randomized, consisting of four treatments and six replications. The tested treatments were: RW - rainwater collected in the EEA $(\mathrm{EC}=0.20 \mathrm{dS}$ $\left.\mathrm{m}^{-1}\right)$; WW - well water $\left(\mathrm{EC}=1.50 \mathrm{dS} \mathrm{m}^{-1}\right) ; \mathrm{EF}$ - cesspool effluent $\left(\mathrm{EC}=3.50 \mathrm{dS} \mathrm{m}^{-1}\right)$; $\mathrm{BW}$ brackish water (obtained by adding commercial $\mathrm{NaCl}$ to well water, $\mathrm{EC}=5.00 \mathrm{dS} \mathrm{m}^{-1}$ ).

The culture used was the sunflower (Helianthus annus L.), genotype Anão de Jardim, supplied by the company "ISLA Sementes", being indicated for the cultivation in pots and considered to be of small size. Sowing was carried out in sowing spots, on 07.07.2019, and 10 days after sowing (DAS), transplanting and application of treatments were carried out, ending the cycle on 09.11.2019.

The soil originated from a profile from the UEFS campus, collected in the $0-150 \mathrm{~cm}$ layer. The natural soil (NS) used in the experiment showed a granulometric composition of $20 \%$ for medium sand, $31 \%$ for fine sand, $9 \%$ for silt and $40 \%$ for clay, and using the methodology suggested by Silva (2009), it was classified as a clay-sandy soil. The chemical characteristics of the natural soil before the treatments were applied are shown in Table 1, being classified by salinity (Richards, 1954) as non-sodium and non-saline and by the degree of sodicity (Massoud, 1971) as non-sodium.

Table 1. Chemical characteristics of natural soil.

\begin{tabular}{|c|c|c|c|c|c|c|c|}
\hline$\underset{\text { (salinity) }}{\mathbf{p H}}$ & $\begin{array}{c}\mathbf{p H} \\
\text { (in water) }\end{array}$ & $\begin{array}{l}\text { Sodium } \\
\text { /cmolc } \mathbf{~ d m}^{-3}\end{array}$ & $\begin{array}{l}\text { Potassium } \\
\text { /cmolc dm } \text { dm }^{-3}\end{array}$ & $\begin{array}{l}\text { Calcium } \\
/ \text { cmolc dm }^{-3}\end{array}$ & $\begin{array}{l}\text { Magnesium } \\
/ \text { cmolc dm }^{-3}\end{array}$ & $\begin{array}{l}\text { Aluminum } \\
\text { /cmolc dm }\end{array}$ & $\begin{array}{c}\text { Potential } \\
\text { acidity } \\
(\mathbf{H}+\mathbf{A l}) \\
\text { /cmolc dm } \\
\end{array}$ \\
\hline 6.20 & 6.22 & 0.17 & 0.18 & 1.71 & 1.60 & 0.00 & 1.98 \\
\hline$\underset{/ \text { cmolc dm }}{\mathrm{Ca}+\mathbf{M g}}$ & $\begin{array}{c}\text { Sum of } \\
\text { bases } \\
/ \mathrm{cmolc} \mathrm{dm}^{-3}\end{array}$ & $\begin{array}{c}\text { Base } \\
\text { saturation } \\
1 \%\end{array}$ & $\begin{array}{c}\text { Organic } \\
\text { matter } \\
/ \mathrm{g} \mathrm{kg}^{-1}\end{array}$ & $\begin{array}{l}\text { Phosphor } \\
/ \mathbf{m g ~ d m}^{-3}\end{array}$ & $\begin{array}{c}\text { CEC } \\
/ \mathrm{cmolc} \mathrm{dm}^{-3}\end{array}$ & $\begin{array}{l}\text { PES } \\
1 \%\end{array}$ & $\begin{array}{c}\text { CEse } \\
/ \mathbf{d S ~ m}^{-1}\end{array}$ \\
\hline 3.31 & 3.66 & 65.00 & 6.00 & 6.00 & 5.64 & 3.01 & 0.81 \\
\hline
\end{tabular}

CEC - cation exchange capacity; PES - percentage of exchangeable sodium; ECse - electrical conductivity of the saturation extract.

The chemical and biological characteristics of the irrigation water used in the sunflower cycle are shown in Table 2.

To obtain the desired electrical conductivity in the treatment with brackish water (BW) commercial $\mathrm{NaCl}$ was added to well water. The amount of sodium chloride $(\mathrm{Q} \mathrm{NaCl})$ used in the preparation of the water was determined from the initial electrical conductivity of the water, using the equation $\mathrm{Q} \mathrm{NaCl}\left(\mathrm{mg} \mathrm{L}^{-1}\right)=640 \mathrm{x}$ (desired $\mathrm{ECw}$ - initial ECw), proposed by Richards (1954), in which $\mathrm{ECw}$ - electrical conductivity of water, in $\mathrm{dS} \mathrm{m}^{-1}$.

The calculation of the blade applied to each container was performed in a spreadsheet, using the Penman-Monteith-FAO method to quantify the reference evapotranspiration, following the calculation methodology presented by Allen et al. (1998) for hourly evapotranspiration data. The data from the UEFS automatic station were obtained every hour, so an evapotranspiration given in $\mathrm{mm} \mathrm{h}^{-1}$ was obtained every hour. Daily evapotranspiration was obtained by calculating the sum of evapotranspiration from the 24 hours prior to the time of irrigation. 
Table 2. Chemical and biological characteristics of irrigation water used in the sunflower cycle.

\begin{tabular}{|c|c|c|c|c|}
\hline PARAMETERS & RW & WW & $\mathbf{E F}$ & BW \\
\hline pH & 7.00 & 6.70 & 8.10 & 7.20 \\
\hline RAS & $3.65 \pm 0.75$ & $8.85 \pm 0.28$ & $16.07 \pm 0.94$ & $65.54 \pm 0.37$ \\
\hline $\mathrm{CE} / \mathrm{dS} \mathrm{m}^{-1}$ & 0.20 & 1.50 & 3.50 & 5.00 \\
\hline Classification by SAR & S1: Low sodium water & $\begin{array}{l}\text { S1: Low sodium } \\
\text { water }\end{array}$ & $\begin{array}{c}\text { S1: Low sodium } \\
\text { water }\end{array}$ & $\begin{array}{l}\text { S4: Very high } \\
\text { sodium water }\end{array}$ \\
\hline Classification by EC & C1: Low salinity water & $\begin{array}{c}\text { C3: High salinity } \\
\text { water }\end{array}$ & $\begin{array}{l}\text { C4: Very high } \\
\text { salinity water }\end{array}$ & $\begin{array}{l}\text { C4: Very high } \\
\text { salinity water }\end{array}$ \\
\hline Hardness/mg L $\mathrm{L}^{-1}$ & $0.07 \pm 0.01$ & $246.67 \pm 1.15$ & $204.00 \pm 12.00$ & $269.33 \pm 2.31$ \\
\hline Alkalinity/mg L $\mathbf{L}^{-1}$ & 2.80 & $30.80 \pm 2.20$ & 985.60 & $22.00 \pm 2.20$ \\
\hline Calcium/mg L ${ }^{-1}$ & 0.00 & $230.70 \pm 1.02$ & $188.32 \pm 12.00$ & $250.78 \pm 1.68$ \\
\hline Magnesium/mg L $\mathrm{L}^{-1}$ & $0.07 \pm 0.01$ & $15.97 \pm 0.54$ & $15.68 \pm 0.25$ & $18.55 \pm 1.59$ \\
\hline Sodium/mg L $\mathbf{L}^{-1}$ & $0.67 \pm 0.13$ & $98.32 \pm 3.11$ & $162.30 \pm 8.20$ & $760.55 \pm 2.76$ \\
\hline Potassium/mg L $\mathrm{L}^{-1}$ & $0.27 \pm 0.05$ & $16.13 \pm 1.36$ & $85.35 \pm 5.87$ & $28.55 \pm 1.63$ \\
\hline Chloride/mg L ${ }^{-1}$ & 10.00 & $464.00 \pm 8.00$ & $546.67 \pm 11.55$ & $2213.33 \pm 23.09$ \\
\hline Phospor/mg L $\mathrm{L}^{-1}$ & 0.00 & 0.00 & $14.47 \pm 0.50$ & 0.00 \\
\hline Nitrogen/mg $\mathbf{L}^{-1}$ & 0.00 & 0.00 & $224.00 \pm 28.00$ & 0.00 \\
\hline BOD/mg L ${ }^{-1}$ & $2.50 \pm 0.71$ & $3.50 \pm 0.71$ & 185.00 & 0.00 \\
\hline $\begin{array}{l}\text { Total solids } \\
\text { /mg L }\end{array}$ & 120.00 & 1060.00 & 1340.00 & $3330.00 \pm 14.14$ \\
\hline $\begin{array}{l}\text { Total coliforms } \\
\text { /MLN 100mL-1 }\end{array}$ & 0.00 & $5.00 \times 10^{2}$ & $8.00 \times 10^{2}$ & $8.00 \times 10^{1}$ \\
\hline $\begin{array}{l}\text { Fecal coliforms } \\
\text { /MLN } 100 \mathrm{~mL}^{-1}\end{array}$ & ABSENT & ABSENT & $5.00 \times 10^{2}$ & $1.00 \times 10^{1}$ \\
\hline
\end{tabular}

RW - rain water; WW - well water; EF - cesspool effluent; BW - brackish water; SAR - sodium adsorption ratio; EC - electric conductivity; BOD - Biochemical oxygen demand; MLN - Most likely number.

The culture evapotranspiration was obtained by the product of daily evapotranspiration with the culture coefficient (Initial, $\mathrm{Kc}=0.60$ for 28 days; Vegetative development, $\mathrm{Kc}=0.95$ for 15 days; Flowering, Kc = 1.09 for 27 days), values recommended by FAO. To determine the daily irrigation volume applied to each pot, the difference between the crop evapotranspiration and the daily precipitation by the pot's surface area was multiplied. On days when precipitation was higher than evapotranspiration, irrigation was not performed. Irrigation was carried out manually using graduated containers, with the soil being irrigated daily in order to maintain the container capacity.

The biometric parameters analyzed were: plant height (PLH), stem diameter (SD), internal (IDC) and external diameter (EDC) of the capitulum, number of leaves (NL), leaf area (LA), number of petals (NP), total fresh phytomass (TFF) and total dry phytomass (TDF). The parameters PH, SD, NL and LA were measured at four points along the cycle, at 20,30, 40 and 50 DAS and the other parameters at the end of the experiment, the plants being harvested when the flower was fully opened.

The water consumption (WC) of the culture was obtained by the difference between the applied volume and the drained volume, and the water-use efficiency (WUE) by the ratio of the TFF to the WC.

At the end of the cycle, soil samples were collected to quantify the salinity parameters. The parameters analyzed were: $\mathrm{pH}$, electrical conductivity of the saturation extract (ECse), content $\left(\mathrm{Na}^{+}\right)$and percentage (PES) of exchangeable sodium.

The results obtained were subjected to analysis of variance (ANOVA), comparing the data by the Tukey Test at the level of 1 and 5\% of probability with the use of the statistical software RStudio. 


\section{RESULTS AND DISCUSSION}

Table 3 presents the chemical characteristics related to soil salinity before and after the sunflower cycle.

Table 3. Soil classification and summary of the analysis of variance of the $\mathrm{pH}$ averages, the electrical conductivity of the soil saturation extract (ECse), the content $\left(\mathrm{Na}^{+}\right)$and the percentage (PES) of exchangeable sodium of the soil before and after the irrigation period.

\begin{tabular}{|c|c|c|c|c|c|c|}
\hline & NS & SRW & SWW & SEF & SBW & $\begin{array}{c}\text { MEAN } \\
\text { SQUARES }\end{array}$ \\
\hline pH (salinity) & $5.50 \mathrm{a}$ & $5.30 \mathrm{a}$ & $5.07 \mathrm{a}$ & $5.20 \mathrm{a}$ & $5.10 \mathrm{a}$ & $0.09^{\text {ns }}$ \\
\hline $\mathrm{CV} / \%$ & 1.82 & 1.89 & 6.93 & 3.85 & 3.92 & \\
\hline ECse/dS m $\mathbf{m}^{-1}$ & $0.81 \mathrm{c}$ & $0.12 \mathrm{~d}$ & $0.86 \mathrm{c}$ & $1.85 \mathrm{~b}$ & $3.10 \mathrm{a}$ & $4.02 * *$ \\
\hline $\mathrm{CV} / \%$ & 3.70 & 16.67 & 5.26 & 1.62 & 3.23 & \\
\hline $\mathrm{Na}^{+} / \mathrm{cmolc} \mathbf{~ d m}^{-3}$ & $0.40 \mathrm{~d}$ & $0.22 \mathrm{e}$ & $0.53 \mathrm{c}$ & $1.29 \mathrm{~b}$ & $2.70 \mathrm{a}$ & $3.13 * *$ \\
\hline $\mathrm{CV} / \%$ & 7.50 & 4.55 & 1.10 & 3.65 & 0.21 & \\
\hline PES/\% & $7.09 \mathrm{c}$ & $3.20 \mathrm{~d}$ & $7.17 \mathrm{c}$ & $15.89 \mathrm{~b}$ & $30.12 \mathrm{a}$ & $349.43 * *$ \\
\hline $\mathrm{CV} / \%$ & 6.53 & 7.66 & 0.51 & 2.21 & 1.07 & \\
\hline $\begin{array}{l}\text { Salinity } \\
\text { classification } \\
\text { Classification } \\
\text { for sodicity }\end{array}$ & $\begin{array}{l}\text { Non-sodium } \\
\text { and non-saline } \\
\text { Not sodic }\end{array}$ & $\begin{array}{l}\text { Non-sodium } \\
\text { and non-saline } \\
\text { Not sodic }\end{array}$ & $\begin{array}{l}\text { Non-sodium } \\
\text { and non-saline } \\
\text { Slightly } \\
\text { sodium }\end{array}$ & $\begin{array}{c}\text { Sodic } \\
\text { Moderately } \\
\text { sodium }\end{array}$ & $\begin{array}{c}\text { Sodic } \\
\text { Excessively } \\
\text { sodium }\end{array}$ & \\
\hline
\end{tabular}

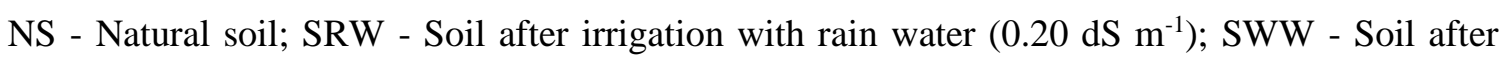
irrigation with well water $\left(1.50 \mathrm{dS} \mathrm{m}^{-1}\right)$; SEF - Soil after irrigation with cesspool effluent ( $3.50 \mathrm{dS}$ $\left.\mathrm{m}^{-1}\right)$; SBW - Soil after irrigation with brackish water $\left(5.00 \mathrm{dS} \mathrm{m}^{-1}\right)$; Means followed by lowercase letters on the same line do not differ statistically by the Tukey test. ${ }^{\text {ns }}$ - not significant; ** significant at $1 \%$ probability; CV - Coefficient of variation.

It can be seen from Table 3 that there was no statistical difference between the $\mathrm{pH}$ of the soil irrigated with the different waters. According to Tan (1982), two factors may have contributed to the non-variation in the $\mathrm{pH}$ of the soil: in the chemical composition of the irrigation water, the amounts of $\mathrm{Na}^{+}$and $\mathrm{Cl}^{-}$are higher than the values of $\mathrm{HCO}^{-}$(alkalinity), prevailing the neutrality of $\mathrm{NaCl}$ with respect to $\mathrm{pH}$, preventing the hydrolysis of $\mathrm{Na}^{+}$which can raise the $\mathrm{pH}$, and there are no considerable concentrations of $\mathrm{Na}_{2} \mathrm{CO}_{3}$ that with water can cause alkaline reactions that can result in a $\mathrm{pH}$ of up to 10; Another factor is associated with the low content of organic matter present in the waters used, since, in waters with a high content of organic matter, during its degradation there is the production of carbon dioxide and release of organic acids that may come to acidify the soil, decreasing its $\mathrm{pH}$.

Such behavior was also evidenced by Andrade Filho et al. (2013) who, when analyzing the soil salinity of cultivated areas, did not observe a significant difference in soil $\mathrm{pH}$ during and after irrigation. Costa et al. (2013) observed that the $\mathrm{pH}$ of the soil increased and stabilized after the middle of the cycle in all treatments in the evaluated soil layers.

The final values of the electrical conductivities of soils irrigated with brackish and wastewater, shown in Table 3, showed significance in relation to the natural soil, changing the salinity condition of the natural soil to a sodium soil, and increased the degree of sodicity of nonsodium for moderately sodic and excessively sodic for soils irrigated with cesspool effluent and brackish water, respectively. The soil irrigated with well water showed no statistical difference, keeping the conductivity close to that of the natural soil, maintaining the salinity condition of the soil in non-sodium and non-saline, with a small increase in sodicity from non-sodium to slightly sodium, different from irrigation with rainwater, which promoted the leaching of salts and promoted the reduction of the electrical conductivity of the soil, keeping the soil as non-sodium and non-saline. 
It appears that, throughout the cycle, the application of well water, cesspool effluent and brackish water promoted an increase in the electrical conductivity of the soil, as shown in Figure 1. The soil irrigated with rainwater maintained the almost constant conductivity, without significant variations throughout the cycle, which may be associated with the low concentration of salts present in this water.

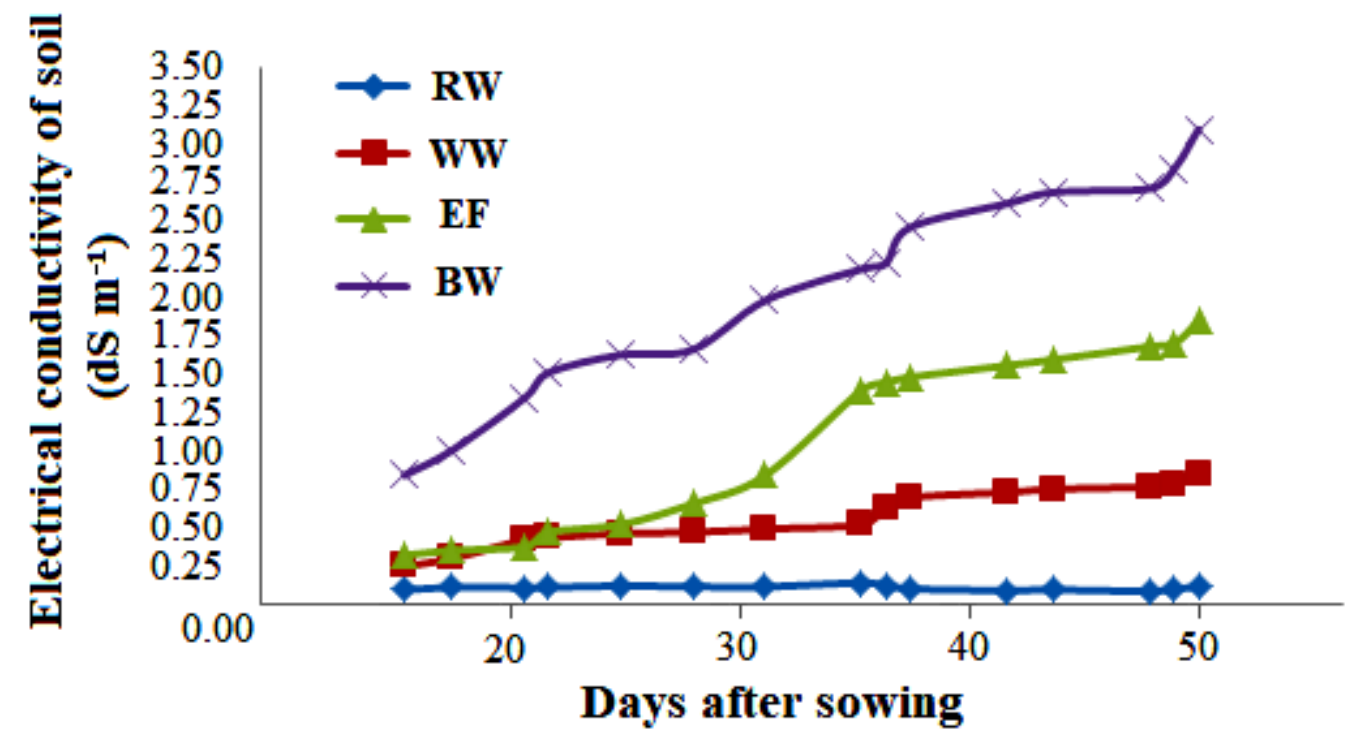

Figure 1. Evolution of the electrical conductivity of the soil along the sunflower cycle as a function of the electrical conductivity of the treatments.

The increase in soil salinity after the use of water rich in salts, maintaining the same irrigation management conditions, is expected, since the greater the electrical conductivity of the water for the same applied volume, the more salts are increased in the soil (Porto Filho et al., 2011).

Regarding the increase in EC of soils irrigated with $\mathrm{BW}$ and $\mathrm{EF}$, it is concluded that under these conditions it would be advisable to apply leaching blades to carry excess salts, since in the Northeast region rainfall is irregular and may not be sufficient to cause the necessary leaching. Similarly, Lima Neto et al. (2015) and Souto et al. (2016) observed that the electrical conductivity of the soil saturation extract increased linearly as a function of the salinity of the irrigation water.

It can be seen from Table 3 that, except in the soil irrigated with rainwater, there was an increase in the concentrations and in the percentage of exchangeable sodium in the irrigated soils in relation to the natural soil. The highest PES was obtained in soil irrigated with brackish water, followed by soil irrigated with the effluent from the well. There was no statistical difference between the PES of the soil irrigated with well water and the natural soil, whereas in the soil irrigated with rain water the PES was statistically inferior to the PES of the natural soil due to the low salinity of this water. Likewise, Nascimento and Fidelis Filho (2015) and Costa et al. (2013) found a significant increase in the PES of cultivated soils when applying water rich in salts.

The significant and growing increase in $\mathrm{Na}^{+}$levels in soils that received WW, BW and EF can be attributed to the chemical composition of these waters, as they contained considerable values of the $\mathrm{Na}^{+}$ion in their composition.

According to the analysis of variance, as shown in Table 4, there was a significant effect at all times of evaluation for the plant height variable, showing the superiority of the average height of plants irrigated with cesspool effluent. Vrânceanu (1977) states that the presence of nitrogen can cause an excessive growth of some biometric parameters of the sunflower, such as plant height, something that can be observed in the present work, where the nitrogen concentrations in the wastewater showed considerable values, which supposedly resulted in the highest average plant height, unlike the other treatments, in which nitrogen was absent. 
Table 4. Summary of the analysis of variance and plant height averages (PLH), in $\mathrm{cm}$, at 20,30, 40 and $50 \mathrm{DAS}$, depending on the salinity of waters of different qualities.

\begin{tabular}{cccccc}
\hline EVALUATION SEASON & RW & WW & EF & BW & MEAN SQUARES \\
\hline 20 DAS & $9.12 \mathrm{~b}$ & $8.80 \mathrm{bc}$ & $15.30 \mathrm{a}$ & $7.23 \mathrm{c}$ & $52.07^{* *}$ \\
CV/\% & 11.53 & 5.75 & 6.45 & 19.97 & \\
30 DAS & $13.64 \mathrm{~b}$ & $13.20 \mathrm{~b}$ & $22.40 \mathrm{a}$ & $10.85 \mathrm{~b}$ & $83.66^{* *}$ \\
CV/\% & 11.39 & 6.34 & 14.96 & 17.25 & \\
40 DAS & $18.54 \mathrm{~b}$ & $16.68 \mathrm{~b}$ & $33.88 \mathrm{a}$ & $14.28 \mathrm{~b}$ & $377.75^{* *}$ \\
CV/\% & 12.70 & 10.34 & 13.54 & 7.44 & \\
50 DAS & $29.68 \mathrm{~b}$ & $23.93 \mathrm{bc}$ & $48.70 \mathrm{a}$ & $20.00 \mathrm{c}$ & $785.93^{* *}$ \\
CV/\% & 8.76 & 7.82 & 16.38 & 8.75 & \\
\hline
\end{tabular}

$\mathrm{RW}$ - rainwater $\left(0.20 \mathrm{dS} \mathrm{m}^{-1}\right)$; WW - well water $\left(1.50 \mathrm{dS} \mathrm{m}^{-1}\right)$; EF - cesspool effluent $\left(3.50 \mathrm{dS} \mathrm{m}^{-1}\right)$ and BW - brackish water $\left(5.00 \mathrm{dS} \mathrm{m}^{-1}\right)$. Means followed by lowercase letters on the same line do not differ statistically by the Tukey test. ${ }^{* *}$ - significant at $1 \%$ probability; CV - Coefficient of variation.

It is observed that even with the second highest salinity, the effluent from the well provided the highest average plant height in all periods of evaluation. Studies have shown that the increase in nitrogen, an organic solute, increases the plants' osmotic adjustment capacity to salinity, also increasing the tolerance of crops to water and salt stress (Lacerda et al., 2003).

For the other treatments tested, there was a decrease in the average plant heights between the periods of evaluation. According to Ayers and Westcot (1999), this occurs due to the addition of salts imposed on the culture, causing negative effects on physiological processes, reducing water absorption by the roots, inhibiting merismatic activity and cellular elongation and reducing plant growth. Likewise, Freitas et al. (2012) observed a positive effect when irrigating sunflower with treated domestic sewage, whereas Maciel et al. (2012), observed that the increase in the electrical conductivity of irrigation water negatively affected the plant-height parameter of the sunflower.

Table 5 presents the summary of the analysis of variance of the stem diameter of sunflower plants at different times of assessment, where it can be seen that irrigation with cesspool effluent provided an increase in the mean diameter of the stem at all times of evaluation with respect to the averages of the other treatments, even with a conductivity of $3.50 \mathrm{dS} \mathrm{m}^{-1}$; this may be related to the presence of nutrients in the effluent, such as nitrogen, phosphorus and potassium. Such elements are essential for the development of crops and do not exist in other treatments. This characteristic was also observed by Andrade et al. (2012), who observed that the diameter of the sunflower stem irrigated with wastewater was greater than that of those irrigated with water supply.

In the treatments with rain, well and brackish water there is a decreasing trend in the average stem diameter with increasing salinity. This characteristic was also observed by Maciel et al. (2012) and Santos Júnior et al. (2016) when verifying a linear decrease in the diameter of the sunflower stem with the increase in salinity.

According to Table 6, it is noted that the number of leaves of plants irrigated with cesspool effluent varied from 12.67 to 27.17 units, statistically higher than the other treatments. It is also noted that the increase in salinity of irrigation water did not cause changes in the development of leaves, presenting conditions of similar evolution throughout the cycle for the number of leaves of plants irrigated with rain, well and brackish water. Similar behavior was observed by Morais et al. (2011), who found that the leaf number parameter was not influenced by the different salinities, showing similar evolution throughout the cycle. Gomes et al. (2015) and Oliveira et al. (2017) observed that the number of sunflower leaves decreased linearly with the increase in irrigation water salinity. 
Table 5. Summary of the analysis of variance and means of stem diameter (SD), in $\mathrm{mm}$, at 20,30, 40 and 50 DAS as a function of the salinity of waters of different qualities.

\begin{tabular}{cccccc}
\hline EVALUATION SEASON & RW & WW & EF & BW & MEAN SQUARES \\
\hline 20 DAS & $5.67 \mathrm{ab}$ & $4.94 \mathrm{~b}$ & $6.89 \mathrm{a}$ & $4.90 \mathrm{~b}$ & $5.21^{* *}$ \\
CV/\% & 17.75 & 9.35 & 13.54 & 14.41 & \\
30 DAS & $5.88 \mathrm{~b}$ & $5.73 \mathrm{~b}$ & $8.67 \mathrm{a}$ & $5.69 \mathrm{~b}$ & $12.70^{* *}$ \\
CV/\% & 16.25 & 9.19 & 7.41 & 12.13 & \\
40 DAS & $6.32 \mathrm{~b}$ & $6.27 \mathrm{~b}$ & $10.81 \mathrm{a}$ & $5.99 \mathrm{~b}$ & $32.12^{* *}$ \\
CV/\% & 10.24 & 10.10 & 6.42 & 11.69 & \\
50 DAS & $6.70 \mathrm{~b}$ & $6.46 \mathrm{~b}$ & $11.88 \mathrm{a}$ & $6.10 \mathrm{~b}$ & $45.11^{* *}$ \\
CV/\% & 10.03 & 10.31 & 9.29 & 12.10 & \\
\hline
\end{tabular}

$\mathrm{RW}$ - rainwater $\left(0.20 \mathrm{dS} \mathrm{m}^{-1}\right)$; WW - well water $\left(1.50 \mathrm{dS} \mathrm{m}^{-1}\right)$; EF - cesspool effluent $\left(3.50 \mathrm{dS} \mathrm{m}^{-1}\right)$ and BW - brackish water $\left(5.00 \mathrm{dS} \mathrm{m}^{-1}\right)$. Means followed by lowercase letters on the same line do not differ statistically by the Tukey test. ** - significant at $1 \%$ probability; CV - Coefficient of variation.

Table 6. Summary of the analysis of variance and means of the number of leaves (NL), in units, at 20,30, 40 and 50 DAS, depending on the salinity of waters of different qualities.

\begin{tabular}{cccccc}
\hline EVALUATION SEASON & RW & WW & EF & BW & MEAN SQUARES \\
\hline 20 DAS & $10.17 \mathrm{~b}$ & $10.17 \mathrm{~b}$ & $12.67 \mathrm{a}$ & $8.67 \mathrm{~b}$ & $16.50^{* *}$ \\
CV/\% & 9.67 & 11.50 & 9.56 & 9.42 & \\
30 DAS & $13.50 \mathrm{~b}$ & $13.83 \mathrm{~b}$ & $22.33 \mathrm{a}$ & $12.83 \mathrm{~b}$ & $121.04^{* *}$ \\
CV/\% & 20.29 & 9.61 & 8.34 & 11.47 & \\
40 DAS & $15.00 \mathrm{~b}$ & $16.33 \mathrm{~b}$ & $27.17 \mathrm{a}$ & $15.50 \mathrm{~b}$ & $202.11^{* *}$ \\
CV/\% & 16.87 & 7.41 & 17.49 & 13.38 & \\
50 DAS & $14.67 \mathrm{bc}$ & $17.67 \mathrm{~b}$ & $23.83 \mathrm{a}$ & $13.83 \mathrm{c}$ & $123.22^{* *}$ \\
CV/\% & 16.51 & 8.52 & 12.28 & 16.75 & \\
\hline
\end{tabular}

$\mathrm{RW}$ - rainwater $\left(0.20 \mathrm{dS} \mathrm{m}^{-1}\right)$; WW - well water $\left(1.50 \mathrm{dS} \mathrm{m}^{-1}\right)$; EF - cesspool effluent $\left(3.50 \mathrm{dS} \mathrm{m}^{-1}\right)$ and BW - brackish water $\left(5.00 \mathrm{dS} \mathrm{m}^{-1}\right)$. Means followed by lowercase letters on the same line do not differ statistically by the Tukey test. ** - significant at $1 \%$ probability; $\mathrm{CV}$ - Coefficient of variation.

According to Morales et al. (2001), not all parts of the plant are affected by salinity, each part of its structure may behave differently and the adaptation to salt stress varies between species, genotypes and phenological stages.

In the leaf-area parameter, it is observed that the plants irrigated with EF were the ones with the highest averages (Table 7). When comparing these plants with those irrigated with brackish water, with a smaller leaf area, there is a superiority in the leaf area of $131.68 ; 464.61 ; 762.14$ and $965.87 \%$ for the evaluation periods of 20,30, 40 and 50 DAS, respectively. Likewise, Santos Júnior et al. (2014) observed that plants irrigated with wastewater obtained the highest values of leaf area in irrigated sunflower plants in relation to plants irrigated with water supply.

Leaf size is associated with the availability of nitrogen, responsible for cell division and/or elongation, and this element not only influences the rate of expansion, but mainly cell division, resulting in the final size of the leaves, making nitrogen the main factor responsible due to the 
rate of biomass accumulation (Taiz and Zeiger, 2013). This explains the fact that the leaves irrigated with effluent present a higher average, even presenting the second highest salinity, unlike the other treatments, where nitrogen was absent. According to Jácome et al. (2005), leaves with a larger leaf area result in a greater photosynthetic surface and in the elevation of the assimilation surface, which results in a higher yield and water control, a fact that may explain the better performance of the parameters previously analyzed of plants irrigated with wastewater.

Table 7. Summary of analysis of variance and averages of leaf area (LA), in $\mathrm{cm}^{2}$, at 20, 30, 40 and 50 DAS, depending on the salinity of waters of different qualities.

\begin{tabular}{cccccc}
\hline EVALUATION SEASON & RW & WW & EF & BW & MEAN SQUARES \\
\hline 20 DAS & $195.56 \mathrm{~b}$ & $184.78 \mathrm{~b}$ & $377.43 \mathrm{a}$ & $162.91 \mathrm{~b}$ & $32661.43^{* *}$ \\
CV/\% & 16.11 & 5.90 & 14.27 & 16.09 & \\
30 DAS & $251.34 \mathrm{~b}$ & $234.98 \mathrm{~b}$ & $973.67 \mathrm{a}$ & $172.45 \mathrm{~b}$ & $834524.71 * *$ \\
CV/\% & 18.67 & 5.76 & 15.30 & 9.44 & \\
40 DAS & $295.66 \mathrm{~b}$ & $280.69 \mathrm{~b}$ & $1854.37 \mathrm{a}$ & $215.09 \mathrm{~b}$ & $3698384.72 * *$ \\
CV/\% & 14.72 & 9.39 & 17.22 & 11.88 & \\
50 DAS & $282.87 \mathrm{~b}$ & $265.03 \mathrm{~b}$ & $2014.61 \mathrm{a}$ & $189.01 \mathrm{~b}$ & $4689202.93 * *$ \\
CV/\% & 13.32 & 14.39 & 11.86 & 15.70 & \\
\hline
\end{tabular}

RW - rainwater $\left(0.20 \mathrm{dS} \mathrm{m}^{-1}\right)$; WW - well water $\left(1.50 \mathrm{dS} \mathrm{m}^{-1}\right)$; EF - cesspool effluent $\left(3.50 \mathrm{dS} \mathrm{m}^{-1}\right)$ and BW - brackish water $\left(5.00 \mathrm{dS} \mathrm{m}^{-1}\right)$. Means followed by lowercase letters on the same line do not differ statistically by the Tukey test. ** - significant at $1 \%$ probability; CV - Coefficient of variation.

In the treatments with rain, well and brackish water, there is a decreasing trend in the leaf area of the plants, also observed by Nobre et al. (2011) and Santos Júnior et al. (2016). According to Tester and Davenport (2003), when there is a decrease in the leaf area of plants in saline conditions, this may be related to a mechanism of adaptation and defense of the plant to saline stress, reducing the volume of cells, the transpirant surface and the loss of water by transpiration, conserving the water supply in the soil for a longer time. However, this reduction decreases productivity by capturing less $\mathrm{CO}_{2}$ and intercepting less light. In addition, the osmotic effect of salt stress can be supported by osmotic regulation of cells, favored by the loss of leaf area and the concentration of organic and inorganic osmoregulators.

Table 8 shows a greater growth of the capitulum and a greater amount of petals in plants irrigated with the cesspool effluent, generating an increase, when compared to plants irrigated with rain water, which obtained the second best yield of $110.69 \%$ in IDC, $57.47 \%$ in EDC and $53.93 \%$ in NP, a fact that may be associated with the nutritional superiority of wastewater, mainly due to the presence of nitrogen and phosphorus absent in other treatments.

The results obtained by Oliveira et al. (2017) corroborate the present research, where the superiority of the parameters of the internal and external diameter of the capitulum and the number of petals of plants irrigated with wastewater in relation to those irrigated with water supply was also evident.

Freitas et al. (2012) state that the diameter of the sunflower capitulum is highly sensitive to salinity, thus being the variable that best expresses the effects of salinity on the sunflower. Thus, the conclusion was that the diameter of the capitulum responded satisfactorily to the salinity of the wastewater effluent of the cesspool, which can be used in irrigation for the cultivation of sunflowers.

Except for the treatment with cesspool effluent, there was a decreasing trend in the IDC and EDC averages with the increase in the electrical conductivity of irrigation water, which may have been caused by the harmful effects that salt stress causes on plants, generated by the difficulty of water entering plant cells due to the reduction of the osmotic potential of the soil due to the 
presence of salts, affecting the development of crops (Tester and Davenport, 2003). Corroborating the results of the present research, Dos Santos et al. (2017) observed that both the internal and the external diameter were reduced linearly with the increase in salinity of irrigation water.

Table 8. Summary of the analysis of variance and means of the internal (DIC) and external diameter (DEC) of the capitulum in $\mathrm{cm}$, and the number of petals (NP), in units, as a function of the salinity of waters of different qualities.

\begin{tabular}{cccccc}
\hline & RW & WW & EF & BW & MEAN SQUARES \\
\hline IDC & $3.18 \mathrm{~b}$ & $3.07 \mathrm{~b}$ & $6.70 \mathrm{a}$ & $2.30 \mathrm{c}$ & $23.15^{* *}$ \\
CV/\% & 13.09 & 11.42 & 7.90 & 12.30 & \\
EDC & $10.18 \mathrm{~b}$ & $9.77 \mathrm{~b}$ & $16.03 \mathrm{a}$ & $8.38 \mathrm{c}$ & $68.67^{* *}$ \\
CV/\% & 5.81 & 4.96 & 4.74 & 2.96 & \\
NP & $24.20 \mathrm{~b}$ & $21.17 \mathrm{~b}$ & $37.25 \mathrm{a}$ & $21.60 \mathrm{~b}$ & $246.95^{* *}$ \\
CV/\% & 14.73 & 1.93 & 10.60 & 9.02 & \\
\hline
\end{tabular}

$\mathrm{RW}$ - rainwater $\left(0.20 \mathrm{dS} \mathrm{m}^{-1}\right)$; WW - well water $\left(1.50 \mathrm{dS} \mathrm{m}^{-1}\right)$; EF - cesspool effluent $\left(3.50 \mathrm{dS} \mathrm{m}^{-1}\right)$ and BW - brackish water $\left(5.00 \mathrm{dS} \mathrm{m}^{-1}\right)$. Means followed by lowercase letters on the same line do not differ statistically by the Tukey test. ** - significant at $1 \%$ probability; $\mathrm{CV}$ - Coefficient of variation.

In the statistical analysis of phytomass, as shown in Table 9, it is observed that in the parameters of fresh and dry phytomass, the means of plants irrigated with cesspool effluent were significantly higher than the other treatments, which is in agreement with the studies by Lucas Filho et al. (2002), who stated that the higher content of nutrients in the soil due to irrigation with wastewater can lead to a better development of the plant, obtaining a greater production of fresh and dry matter. Such superiority in the phytomass of plants irrigated with wastewater was also observed by Oliveira et al. (2017).

Table 9. Summary of analysis of variance and averages of total fresh (TFF) and dry (TDF) phytomass, in grams, water consumption (WC), in $\mathrm{L} \mathrm{plant}^{-1}$, and water use efficiency (WUE) in $\mathrm{kg} \mathrm{m}^{-3}$, depending on the salinity of waters of different qualities.

\begin{tabular}{cccccc}
\hline & RW & WW & EF & BW & MEAN SQUARES \\
\hline TFF & $42.52 \mathrm{~b}$ & $38.30 \mathrm{~b}$ & $208.90 \mathrm{a}$ & $25.97 \mathrm{~b}$ & $42144.17 * *$ \\
CV/\% & 20.78 & 16.63 & 16.71 & 4.45 & \\
TDF & $7.37 \mathrm{~b}$ & $5.87 \mathrm{~b}$ & $34.01 \mathrm{a}$ & $3.89 \mathrm{~b}$ & $1123.17 * *$ \\
CV/\% & 18.67 & 15.40 & 20.89 & 3.21 & \\
WC & $8.00 \mathrm{~b}$ & $7.42 \mathrm{~b}$ & $9.04 \mathrm{a}$ & $6.67 \mathrm{c}$ & $9002072.69 * *$ \\
CV/\% & 2.68 & 2.09 & 3.49 & 3.82 & \\
WUE & $1.02 \mathrm{~b}$ & $0.89 \mathrm{~b}$ & $3.67 \mathrm{a}$ & $0.58 \mathrm{c}$ & $7.65 * *$ \\
CV/\% & 4.20 & 6.95 & 2.17 & 3.21 & \\
\hline
\end{tabular}

RW - rainwater $\left(0.20 \mathrm{dS} \mathrm{m}^{-1}\right)$; WW - well water $\left(1.50 \mathrm{dS} \mathrm{m}^{-1}\right)$; EF - cesspool effluent $\left(3.50 \mathrm{dS} \mathrm{m}^{-1}\right)$ and BW - brackish water $\left(5.00 \mathrm{dS} \mathrm{m}^{-1}\right)$. Means followed by lowercase letters on the same line do not differ statistically by the Tukey test. ** - significant at $1 \%$ probability; CV - Coefficient of variation.

It is noted that the application of wastewater provided an increase of $391.30 \%, 445.43 \%$ and $704.39 \%$ in relation to the treatments with rain water, well water and brackish water, respectively, in the TFF. As for the TDF parameter, the cesspool effluent was higher in relation to rain, well and brackish water, about $361.47 \%, 479.39 \%$ and $774.29 \%$, respectively, which reinforces the use of wastewater in irrigation, and may exempt the need for additional costs with fertilizer and manures to increase the development and productivity of the crop.

The study of dry plant phytomass constitutes one of the most important parameters to be evaluated in a crop subjected to different treatments because it represents the result of 
photosynthetic activity and the absorption of mineral elements in the soil; that is, it represents the product of liquid photosynthesis, which is the difference between crude photosynthesis (everything that is produced inside chloroplasts) and what is consumed by breathing, and this parameter is related to the leaf area, becoming crucial for understanding the development of the culture (Peixoto and Peixoto, 2009).

Regarding the water consumption of sunflower, it is observed that wastewater was the one that presented the highest consumption, which may be related to the greater development of the crop due to the high nutritional content of the sewage, which generated larger plants in size and weight, which consequently generates a higher consumption of water by the crop. The analysis of variance for the water use efficiency parameter (WUE) shows the superiority of the total dry phytomass production per cubic meter of water applied with the cesspool effluent, presenting a better yield over the other treatments, where the wastewater provided an increase in dry mass of $259.80 \%, 312.36 \%$ and $532.76 \%$ with respect to rain, well and brackish water, respectively, which may have induced the plants to a higher water consumption. This reinforces the statement by Lucas Filho et al. (2002), that the introduction of nutrients in the soil may increase the dry mass production of the crops, as well as result in a better production yield; that is, a better capacity to convert the volume of water applied in dry mass.

It is observed in Table 9 that in all parameters evaluated, except for the treatment with effluent from the cesspool, there was a reduction in the averages with the increase in salinity, which is in accordance with Munns (2005), who states that the increase of salts in the root zone tends to reduce the levels of water consumption by plants, causing water stress and decreasing the osmotic potential of the soil solution and in the flow of water, in the sense of soil-plantatmosphere. The same author also states that, by increasing the electrical conductivity of the water, the strain necessary for the plant to remove water from the soil is also increased, making the soil potential increasingly negative, making it difficult to absorb this water, which despite presence in the soil is not fully available to plants.

Centeno et al. (2014) and Travassos et al. (2012) observed reductions in phytomasses with increased salinity. Travassos et al. (2019) observed a decrease in water consumption with an increase in the electrical conductivity of irrigation water. Nobre et al. (2014) and Medeiros et al. (2012) found a decrease in the efficiency of water use with the increase in salinity.

\section{CONCLUSIONS}

The irrigation waters did not affect the soil $\mathrm{pH}$; however, they promoted an increase in the electrical conductivity, in the content and in the percentage of exchangeable sodium of the soils, except for the soils irrigated with rainwater.

For the treatments with rain water, well water and brackish water, a decreasing trend was observed with the increase in salinity in the parameters of phytomass, PLH, SD, NL, LA, IDC, EDC, WC and WUE.

The use of brackish water reduced the majority of sunflower growth parameters, and its use for crop irrigation is not advisable.

Rainwater, well water and wastewater can be used in irrigation in environments of water scarcity, such as arid and semi-arid regions.

Wastewater provided the best crop development for the parameters of growth, consumption and water use efficiency.

\section{ACKNOWLEDGMENT}

The Coordination for the Improvement of Higher Education Personnel (CAPES) for the financial support. 


\section{REFERENCES}

AHMADIFARD, S. Impact of wastewater irrigation on concentration and absorption of nutrients and heavy metals in barley in calcareous soils. Journal of Biodiversity and Environmental Sciences, v. 5, n. 4, p. 453-460, 2014.

ALLEN, R. G.; PEREIRA, L. S.; RAES, D.; SMITH, M. Crop evapotranspiration. Rome: FAO, 1998. 300 p. (FAO Irrigation and Drainage Paper, n. 56).

AMINIFARD, M. H.; AROIEE, H.; FATEMI, H.; AMERI, A.; KARIMPOUR, S. Responses of eggplant (Solanum melongena L.) to different rates of nitrogen under field conditions. Journal Central European Agriculture, v. 11, p. 453-458, 2010.

ANDRADE, L. O.; GHEYI, H. R.; NOBRE, R. G.; DIAS, N. S.; NASCIMENTO, E. C. S. Crescimento de girassóis ornamental em sistema de produção orgânica e irrigada com água residuária tratada. Irriga, v. 1, Edição Especial, p. 69-82, 2012. https://doi.org/10.15809/irriga.2012v1n01p69

ANDRADE FILHO, J.; SOUSA NETO, O. N.; DIAS, N. da S.; NASCIMENTO, I. B. do; MEDEIROS, J. F.; COSME, C. R. Atributos químicos de solo fertirrigado com água residuária no semiárido brasileiro. Irriga, v. 18, n. 4, p. 661 - 674, 2013. https://doi.org/10.15809/irriga.2013v18n4p661

AYERS, R. S.; WESTCOT, D. W. A qualidade da água na agricultura. 2. ed. Campina Grande: UFPB, 1999. 218p. (Estudos FAO. Irrigação e Drenagem, 29).

AZEVEDO, J.; DUTRA, I. C. B.; COSTA, F. G. B.; BATISTA, R. O.; COSTA, L. R. Alterações químicas de cambissolo fertirrigado com água residuária doméstica tratada. Revista Agropecuária Científica no Semiárido, v. 9, n. 2, p. 66-76, 2013.

CENTENO, C. R. M.; SANTOS, J. B. dos; XAVIER, D. A.; AZEVEDO, C. A. V. de; GHEYI, H. R. Componentes de produção do girassol Embrapa 122-V2000 sob salinidade da água e adubação nitrogenada. Revista Brasileira de Engenharia Agrícola e Ambiental, v. 18, p. 39-45, 2014.

COSTA, M. E. da; MORAIS, F. A.; SOUZA, W. C. M.; GURGEL, M. T.; OLIVEIRA, F. H. T. Estratégias de irrigação com água salina na mamoneira. Revista Ciência Agronômica, v. 44, n. 1, p. 34-43, 2013. http://dx.doi.org/10.1590/S1806-66902013000100005

COSTA, F. G. B.; OlIVEIRA, A. F. M.; CARVAlHO, M. A. B.; FERNANDES, M. B.; BATISTA, R. O. Desenvolvimento inicial de cultivares de melão fertirrigadas com distintas proporções de esgoto doméstico em Mossoró-RN. Revista Caatinga (Online), v. 27, p. 116-123, 2014.

DIAS, N. da S.; BLANCO, F. F.; SOUZA, E. R. de; FERREIRA, J. F. da; SOUSA NETO, O. N. de; QUEIROZ, I. S. de. Efeito dos sais na planta e tolerância das culturas a salinidade. In: GHEYI, H. R.; DIAS, N. da S.; LACERDA, C. F. de.; GOMES FILHO, E. (eds.). Manejo da Salinidade na Agricultura: Estudos Básicos e Aplicados. 2. ed. Fortaleza: INCTSal, 2016.

DOS SANTOS, J. B.; CENTENO, C. R. M.; AZEVEDO, C. A. V. de; GHEYI, H. R.; LIMA, G. S.; LIRA, V. M. Crecimiento del girasol (Helianthus annuus L.) en función de la salinidad del agua de riego con fertilización nitrogenada. Revista Agrociencia, v. 51, p. 649-660, 2017. 
FREITAS, C. A. S.; SILVA, A. R. A. da; BEZERRA, F. M. L.; ANDRADE, R. R. de; MOTA, F. S. B.; AQUINO, B. F. Crescimento da cultura do girassol irrigado com diferentes tipos de água e adubação nitrogenada. Revista Brasileira de Engenharia Agrícola e Ambiental, v. 16, n.10, p. 1031-1039, 2012. http://dx.doi.org/10.1590/S141543662012001000001

GOMES, K. R.; SOUSA, G. G. de; LIMA, F. A.; VIANA, T. V. A.; AZEVEDO, B. M. de; SILVA, G. L. Irrigação com água salina na cultura do girassol (Helianthus annuus L.) em solo com biofertilizante bovino. Irriga, v. 20, n.4, p. 680-693, out-dez, 2015. https://doi.org/10.15809/irriga.2015v20n4p680

JÁCOME, A. G.; FERNANDES, P. D; GHEYI, H. R; GONÇALVES, A. C. A; SILVA, F. F. da. Avaliação de genótipos de algodoeiro sob níveis de salinidade da água de irrigação. Revista Brasileira de Engenharia Agrícola e Ambiental, v. 9, p. 365-369, 2005.

JORGE, M. F; PINHO, C. F.; NASCENTES, A. L.; ALVES, D. G.; ALMEIDA, G. V.; SILVA, J. B. G.; SILVA, L. D. B. Tomato fertigation with dairy cattle wastewater. Horticultura Brasileira, v. 35, p. 230-234, 2017. https://doi.org/10.1590/s0102-053620170212

LACERDA, C. F.; CAMBRAIA, J.; OLIVA, M. A.; RUIZ, H. A.; PRISCO, J. T. Solute accumulation and distributions during shoot and development in two sorghum genotypes under salt stress. Environmental and Experimental of Botany, v. 49, n.1, p.107-120, 2003. https://doi.org/10.1016/S0098-8472(02)00064-3

LIMA NETO, A. J.; CAVALCANTE, L. F.; NUNES, J. C.; SOUTO, A. G. L.; BEZERRA, F. T. C. Mudas de tamarindeiro irrigadas com água salina em solo sem e com biofertilizantes. Irriga, v. 20, n. 4, p. 730-744, 2015. https://doi.org/10.15809/irriga.2015v20n4p730

LUCAS FILHO, M.; PEREIRA, M. G.; SILVA, D. A.; NETO, C. O. A.; MELO, H. N. S.; SILVA, G. B. Águas residuárias - Alternativa de reúso na cultura de girassol (Helianthus annuus L.). In: SIMPÓSIO ÍTALO BRASILEIRO DE ENGENHARIA SANITÁRIA E AMBIENTAL, 6., 2002, Vitória. Anais[...]. Rio de Janeiro: ABES, 2002.

MACIEL, M. P.; SOARES, T. M.; GHEYI, H. R.; REZENDE, E. P. L.; OLIVEIRA, G. X. S. Produção de girassol ornamental com uso de águas salobras em sistema hidropônico NFT. Revista Brasileira de Engenharia Agrícola e Ambiental, v. 16, n. 2, p. 165-172, 2012. https://doi.org/10.1590/S1415-43662012000200006

MALAFAIA, G.; ARAUJO, F. G.; LEANDRO, W. M.; RODRIGUES, A. S. L. Teor de nutrientes em folhas de milho fertilizado com vermicomposto de lodo de curtume e irrigado com água residuária doméstica. Revista Ambiente \& Água, v. 11, p. 799, 2016. https://doi.org/10.4136/ambi-agua.1680

MASSOUD, F. I. A note on the need for accented definitions and method of characterization of salts affected soils. In: REUNION DE LA SUBCOMISÍON DE SUELOS SALINOS, 1971, Sevilla. Anais[...] Sevilla: Iryda, 1971.

MEDEIROS, P. R. F.; DUARTE, S. N.; SILVA, E. F. F. Eficiência do uso de água e de fertilizantes no manejo de fertirrigação no cultivo do tomateiro sob condições de salinidade do solo. Agrária, v. 7, p. 344-351, 2012. https://dx.doi.org/10.5039/agraria.v7i2a1563

MORAIS, F. A.; GURGEL, M. T.; OLIVEIRA, F. H. T.; MOTA, A. F. Influência da irrigação com água salina na cultura do girassol. Revista Ciência Agronômica, v. 42, n. 2, p. 327336, 2011. https://doi.org/10.1590/S1806-66902011000200010 
MORALES, M. A.; OLMOS, E.; TORRECILLAS, A.; ALARCON, J. J. Differences in water relations, leaf ion accumulation and excretion rates between cultivated and wild species of Limonium sp. grown in conditions of saline stress. Flora, v. 196, n. 5, p. 345-352, 2001. https://doi.org/10.1016/S0367-2530(17)30070-1

MUNNS, R. Genes and salt tolerance: bringing them together. New Phytologist, v. 167, n. 3, p. 645-663, 2005. https://doi.org/10.1111/j.1469-8137.2005.01487.x

NASCIMENTO, J. S.; FIDELES FILHO, J. Crescimento, Produção e Alterações Químicas do Solo em Algodão Irrigado com Água de Esgotos Sanitários Tratados. Revista Caatinga, v. 28, n. 2, p. 36-45, 2015.

NOBRE, R. G.; GHEYI, H. R.; SOARES, F. A. L.; CARDOSO, J. A. F. Produção de girassol sob estresse salino e adubação nitrogenada. Revista Brasileira de Ciência do Solo, v. 35, p. 929-937, 2011. https://doi.org/10.1590/S0100-06832011000300027

NOBRE, R. G.; LIMA, G. S.; GHEYI, H. R.; SOARES, L. A. A.; SILVA, A. O. Crescimento, consumo e eficiência do uso da água pela mamoneira sob estresse salino e nitrogênio. Revista Caatinga, v. 27, p. 148-158, 2014.

OLIVEIRA, M. L. A.; PAZ, V. P. S.; GONCALVES, K. S.; OLIVEIRA, G. X. S. Crescimento e Produção de Girassol Ornamental Irrigado com Diferentes Lâminas e Diluições de Água $\begin{array}{llllllll}\text { Residuária. } & \text { Irriga, } & \text { v. } 22, & \text { n. } & 2, & \text { p. } & \text { 204-219, }\end{array}$ https://doi.org/10.15809/irriga.2017v22n1p204-219

PEIXOTO, C. P.; PEIXOTO, M. F. S. P. Dinâmica do Crescimento Vegetal (Princípios Básicos). In: CARVALHO, C. A. L.; DANTAS, A. C. V. L.; PEREIRA, F. A. C.; SOARES, A. C. F.; MELO FILHO, J. F. (Org.). Tópicos em Ciências Agrárias. 1. ed. Cruz das Almas BA: Editora Nova Civilização, 2009. v. 1. p. 37-53.

PORTO FILHO, F. Q.; MEDEIROS, J. F.; GHEYI, H. R.; DIAS, N. S.; SOUSA, P. S.; DANTAS, D.C. Evolução da salinidade e $\mathrm{pH}$ de um solo sob cultivo de melão irrigado com água salina. Revista Brasileira de Engenharia Agrícola e Ambiental, v. 15, p. 1130-1137, 2011. https://doi.org/10.1590/S1415-43662011001100004

RICHARDS, L. A. (Ed). Diagnosis and improvement of saline and alkali soils. Washington, DC: United States Salinity Laboratory Staff, USDA, 1954. 160p. (Agriculture Handbook, $60)$.

SALGADO, V. C.; SOUZA FILHO, E. J.; GAVAZZA, S.; FLORENCIO, L.; KATO, M. T. Cultivo de melancia no semiárido irrigado com diferentes lâminas de esgoto doméstico tratado. Engenharia Sanitária e Ambiental, v. 23, p. 727-738, 2018. https://doi.org/10.1590/s1413-41522018161706

SANTOS JÚNIOR, J. A.; GHEYI, H. R.; DIAS, N. S.; MEDEIROS, S. de S.; GUEDES FILHO, D. H. Substratos e tempo de renovação da água residuária no crescimento do girassol ornamental em sistema semi-hidroponia. Revista Brasileira de Engenharia Agrícola e Ambiental, v. 18, p. 790-797, 2014. https://doi.org/10.1590/18071929/agriambi.v18n08p790-797

SANTOS JÚNIOR, J. A.; GHEYI, H. R.; CAVALCANTE, A. R.; FRANCILINO, A. H.; PEREZ-MARIN, A. M. Crescimento de Girassóis Ornamentais Sob Estresse Salino em Hidroponia de Baixo Custo. Irriga, v. 21, n. 3, p. 591-604, 2016. https://doi.org/10.15809/irriga.2016v21n3p591-604 
SILVA, F. C. da (Ed.). Manual de análises químicas de solos, plantas e fertilizantes. 2. ed. Brasília, DF: Embrapa Informação Tecnológica.; Rio de Janeiro: Embrapa Solos, 2009. 627 p. il.

SILVA, V. F.; BEZERRA, C. V. C.; NASCIMENTO, E. C. S.; FERREIRA, T. N. F.; LIMA, V. L. A.; ANDRADE, L. O. Production of chili pepper under organic fertilization and irrigation with treated wastewater. Revista Brasileira de Engenharia Agrícola e Ambiental, v. 23, p. 84-89, 2019. https://doi.org/10.1590/1807-1929/agriambi.v23n2p8489

SILVEIRA, J. A. G.; SILVA, S. L. F.; SILVA, E. N.; VIÉGAS, R. A. Mecanismos biomoleculares envolvidos com a resistência ao estresse salino em plantas. In: GHEYI, H. R.; DIAS, N. da S.; LACERDA, C. F. de.; GOMES FILHO, E. (eds.). Manejo da Salinidade na Agricultura: Estudos Básicos e Aplicados. 2. ed. Fortaleza: INCTSal, 2016.

SOUTO, A. G. L.; CAVALCANTE, L. F.; LIMA NETO, A. J.; MESQUITA, F. O.; SANTOS, J. B. Biometria em plantas de noni sob irrigação com águas Salinas e lixiviação dos sais do solo. Revista Ciência Agronômica, v. 47, n. 2, p. 316-324, 2016.

TAIZ, L.; ZEIGER, E. Fisiologia vegetal. 5. ed. Porto Alegre: Artmed, 2013. 918 p.

TAN, K. H. Principles of soil chemistry. New York: Marcel Dekker, 1982. 267p.

TESTER, M.; DAVENPORT, R. $\mathrm{Na}^{+}$tolerance and $\mathrm{Na}^{+}$transport in higher plants. Annals of Botany, v. 91, n. 5, p. 503-527, 2003. https://doi.org/10.1093/aob/mcg058

TRAVASSOS, K. D.; GHEYI, H. R.; SOARES, F. A. L.; BARROS, H. M. M.; DIAS, N. S.; UYEDA, C. A.; SILVA, F. V. Crescimento e desenvolvimento de variedades de girassol irrigado com água salina. Irriga, v.1, p.324-339, 2012. https://doi.org/10.15809/irriga.2012v1n01p324

TRAVASSOS, K. D.; GHEYI, H. R.; BARROS, H. M. M.; SOARES, F. A. L.; UYEDA, C. A.; DIAS, N. S.; GURGEL, M. T.; CHIPANA-RIVERA, R. Water consumption of the sunflower crop watered with saline water. DYNA, v. 86, p. 221-226, 2019. https://dx.doi.org/10.15446/dyna.v86n208.73203

VRÂNCEANU, A. V. El girassol. Madri: Editora Mundi Prensa, 1977. 375p. 